\title{
X-Cephalometric Study of Different Parts of the Upper Airway Space and Changes in Hyoid Position following Mandibular Fractures
}

\author{
L-J Chen ${ }^{1}$, M-C Zhao ${ }^{2}$, X-F Pan², Y-Q Wei², D-Y Wang ${ }^{2}$
}

\begin{abstract}
Objective: This study analyses the different parts of the upper airway space and the changes in hyoid position. The results provide a clinical reference for developing timely and effective treatment programmes for patients with mandibular fractures caused by maxillofacial trauma.

Methods: Standard X-cephalometric measurements of the lateral skull of 210 subjects were taken. The subjects were divided into four fracture groups: condylar, mandibular angle, mandibular body, and parasymphyseal.

Results: The radiographs of the mandibular fracture groups were compared with the normal occlusion group to analyse the upper airway space and the changes in hyoid position. Different types of fractures have different effects on the upper airway space. Bilateral mandibular body fracture and the parasymphyseal fracture have a significant influence on the lower oropharyngeal and laryngopharyngeal airway spaces, with serious obstructions severely restricting the ventilatory function of patients.

Conclusions: Fractures at different parts of the mandibular structure are closely related to the upper airway and hyoid position.
\end{abstract}

Keywords: Hyoid position, mandibular condylar fracture, mandibular fracture, upper airway space, x-ray cephalometry

\section{Estudio Cefalométrico con Rayos X de Diferentes Partes del Espacio de las Vías Respiratorias Superiores y Cambios en la Posición Hioidea tras Fracturas Mandibulares

\author{
L-J Chen ${ }^{1}$, M-C Zhao ${ }^{2}$, X-F Pan², Y-Q Wei², D-Y Wang ${ }^{2}$
}

\begin{abstract}
RESUMEN
Objetivo: Este estudio analiza las diferentes partes del espacio de las vías respiratorias superiores y los cambios de posición hioidea. Los resultados proporcionan una referencia clínica para desarrollar programas de tratamiento oportuno y eficaz para los pacientes con fracturas de la mandíbula, causadas por trauma maxilofacial.

Métodos: Se hicieron mediciones X-cefalométricas estándares del cráneo lateral a 210 sujetos. Los sujetos fueron divididos en cuatro grupos de fractura: ángulo mandibular, condilar, cuerpo mandibular $y$ parasinfisaria.

Resultados: Las radiografias de los grupos de fractura mandibular fueron comparadas con el grupo de oclusión normal para analizar el espacio de las vías respiratorias superiores y los cambios de posición hioidea. Diferentes tipos de fracturas tienen diferentes efectos sobre el espacio de las vías respiratorias superiores. La fractura de cuerpo mandibular bilateral y la fractura de parasinfisaria tienen una influencia significativa en los espacios de las vías respiratorias orofaríngea y laringofaríngea inferiores, con serios obstáculos restringiendo severamente la función respiratoria de los pacientes. Conclusiones: Las fracturas en diferentes partes de la estructura mandibular se hallan estrechamente vinculadas a las vías respiratorias superiores y a la posición hioidea.
\end{abstract}

From: ${ }^{1}$ Department of Respiration and ${ }^{2}$ Department of Oral and Maxillofacial Surgery, $3^{\text {rd }}$ Hospital of Hebei Medical University, Shijiazhuang, China.
Correspondence: Dr M-C Zhao, Department of Oral and Maxillofacial Surgery, $3^{\text {rd }}$ Hospital of Hebei Medical University, Shijiazhuang 050051, China. E-mail: minchaozhao@yeah.net 
Palabras claves: Posición hioidea, fractura condilar mandibular, fractura mandibular, espacio de las vías respiratorias superiores, cefalometría de rayos $\mathrm{x}$

West Indian Med J 2013; 62 (7): 643

\section{INTRODUCTION}

Mandibular fractures are a common type of facial trauma and account for $60 \%$ of maxillofacial fractures. A mandibular fracture causes the displacement of fractured bone sections and is affected by many factors, such as location of the fracture, magnitude, and orientation of the damaging and traction forces of the muscle. Based on fracture location, mandibular fractures can be categorized into 1) mandibular condylar fracture, 2) coracoids fracture, 3) ramus fracture, 4) mandibular angle fracture, 5) mandibular body fracture, 6) parasymphyseal fracture, and 7) alveolar process fracture (1).

Studies on the upper airway mainly address obstructive sleep apnoea syndrome, orthodontics, and orthognathics, as well as cleft lip and palate areas. These studies seldom focus on the upper airway space of patients with mandibular fractures and relevant craniofacial morphology. We therefore conducted preliminary research on the upper airway space and changing hyoid position in mandibular condylar fracture, mandibular angle fracture, mandibular body fracture, and parasymphyseal fracture. We also evaluated the posttraumatic respiratory function of patients. The results are intended to provide theoretical support for the efficient assessment of risk factors in trauma patients, necessity for surgery, degree of difficulty of anaesthetic intubation, and postoperative prognosis.

\section{SUBJECTS AND METHODS}

A total of 210 subjects were recruited for this study. Ethical approval to conduct this study was obtained from the Ethics Committee of the Third Hospital of Hebei Medical University in accordance with the Declaration of Helsinki. Written informed consent was obtained from all participants.

Normal occlusion group: The group comprised 30 adults (all males) between ages 18 and 35 years. They were chosen among internship students/graduate volunteers from Hebei Medical University. Only individuals with neutral molar relationships and normal mandibular functions were included. The cephalometric measurements of the group were $0^{\circ}$ $<\mathrm{ANB}<5^{\circ}$; $\mathrm{SN}-\mathrm{MP}<40^{\circ}$.

Mandibular fracture group: The patients were chosen from those treated at the Oral and Maxillofacial Surgery Department of the Third Hospital of Hebei Medical University from January 2008 to January 2010. Based on imaging inspection and examination of signs and symptoms three days after maxillofacial trauma, 20 patients were diagnosed with unilateral mandibular condylar fracture and 20 with bilateral mandibular condylar fracture, 22 with unilateral mandibular angle fracture and 22 with bilateral mandibular angle fracture, 18 with unilateral mandibular body fracture and 18 with bilateral mandibular body fracture, 30 with parasymphyseal single-line and 30 with parasymphyseal comminuted fracture. Cephalometric measurements were $0^{\circ}<\mathrm{ANB}<5^{\circ}$; SN$\mathrm{MP}<40^{\circ}$.

Full-time analysts from the Radiology Department of the hospital obtained the lateral skull radiographs of the patients using a dedicated X-ray camera (CRANEX 3+ $\mathrm{CEPH}$ for cephalometry, produced by Finnish Soredex) under consistent shooting conditions. The conventional lateral skull radiographs were measured and plotted on parchment paper using the tracing method. Each image was measured three times to obtain the average value (resolution: $0.01 \mathrm{~mm}$ ). The measurement value of each image was equal to the actual length measured or to the magnification to eliminate the errors caused by image magnification during projection.

This study combined the criteria adopted from Liu (2), Fu (3), Lowe (4), Hiyama (5), Han (6) and Ferguson (7). Twenty index points (ie those of the hard maxillofacial tissues, upper airway, soft palate, hyoid and cervical vertebra) and four datum planes were measured; 12 measurements for the upper airway (four), soft palate (three), hyoid (four) and head position (one) were also used. Figures 1 to 4 present the details.

Microsoft Excel data management software (SPSS 13.0) was used to build the database. Analysis of variance (ANOVA) and Dunnett's test were used to compare the measured items of the mandibular condylar fracture group, mandibular angle fracture group, mandibular body fracture group, and parasymphyseal fracture group with those of the normal occlusion group.

\section{RESULTS}

\section{Mandibular condylar fracture group}

The space in the lower oropharyngeal airway (PAS) in the bilateral mandibular condylar fracture group was significantly reduced $(p<0.05)$, the height of the hyoid from the MP plane (H-MP) significantly decreased $(p<0.05)$, and the craniocervical angle (CVT/SN) significantly increased $[p<0.05]$ (Table 1).

\section{Mandibular angle fracture group}

The space in the laryngopharyngeal airway (V-LPW) in the bilateral mandibular angle fracture group was significantly reduced $(p<0.05)$, whereas that in the CVT/SN significantly increased $[p<0.05]$ (Table 2). 


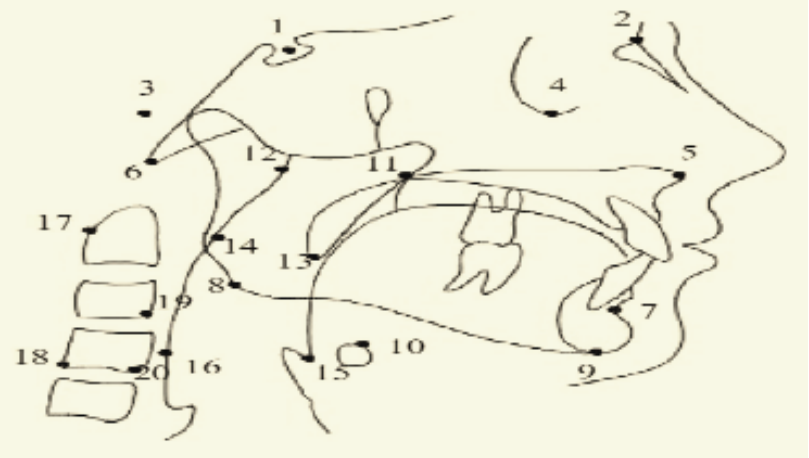

Fig. 1: Index points measured.1) sella turcica point (S);2) nasion point $(\mathrm{N})$; 3) auriculare (P); 4) orbitale (Or); 5) prenasospinale (ANS); 6) basion (Ba); 7) supramental (B); 8) gonion (go); 9) gnathion (Me); 10) me hyoid point; 11) postnasospinale (PNS); 12) upper pharynx wall point (UPW): the intersection between PNS-Ba line and posterior pharynx wall; 13) U soft palate tip; 14) middle pharynx wall point (MPW): foot of the perpendicular from $U$ to the posterior pharynx wall; 15) epiglottis valley (V);16) low pharynx wall point (LPW): foot of the perpendicular from $\mathrm{V}$ to the posterior pharynx wall; 17) Cv2ig: final upper edge point of the second cervical vertebra; 18) Cv4ip: last lower edge point of the fourth cervical vertebra; 19) C3: front most lower edge point of the third cervical vertebra; and 20) C4: final lower edge point of the fourth cervical vertebra.

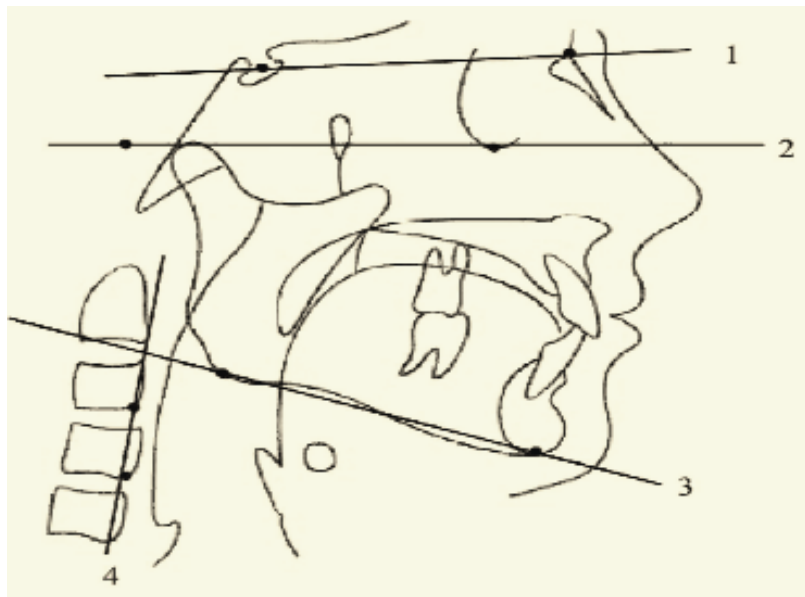

Fig. 2: Datum plane. 1) Sn anterior cranial base plane: the connecting line between $\mathrm{S}$ and $\mathrm{N}$ points; 2) FH: ear plane or facial horizontal plane, $P$ point: connecting line between P point (ear point) and Or point (socket point); 3) MP (mandibular plane): tangential from the lower edge of the mandibular angle through Me (gnathion); and 4) front plane of the CVP cervical vertebra, connecting line between $\mathrm{C} 3$ point and $\mathrm{C} 4$ point.

\section{Mandibular body fracture group}

The space in the V-LPW was significantly reduced $(p<0.05)$. The same results were observed in the PAS in the bilateral mandibular body fracture group $(p<0.05)$ and in the V-LPW $(p<0.01)$. The height of the hyoid against the $\mathrm{FH}$ plane (H$\mathrm{FH})$ significantly increased $(p<0.05)$. The front and back positions of the hyoid (H-CVP) and that against the sella

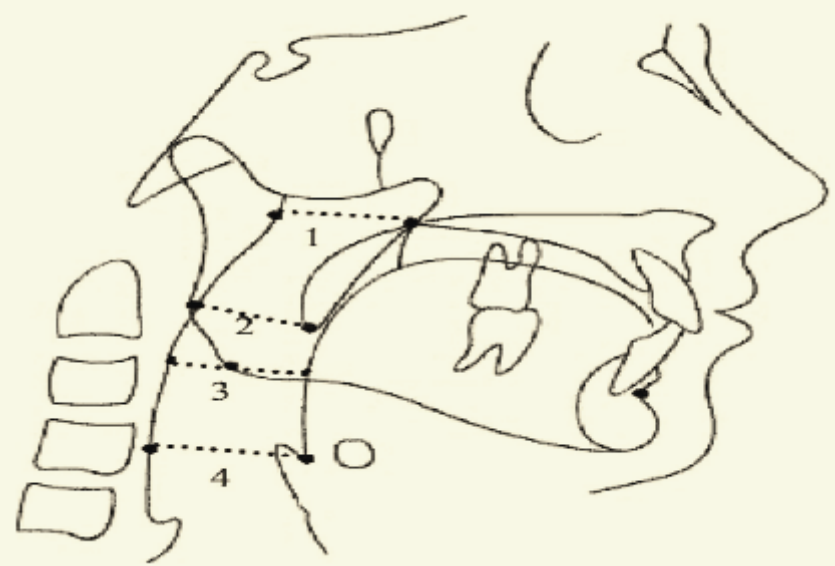

Fig. 3: Measured items in the upper airway. 1) PNS-UPW: distance from the postnasospinale to the upper pharynx wall representing the space in the nasopharyngeal airway; 2) U-MPW: distance from the uvula tip to the middle pharynx wall representing the space in the upper oropharyngeal airway; 3) PAS: space in the lower oropharyngeal airway/the space in the airway at the root of the tongue; and 4) V-LPW: distance from the epiglottic vallecula to the lower pharynx wall representing the space in the laryngopharyngeal airway.

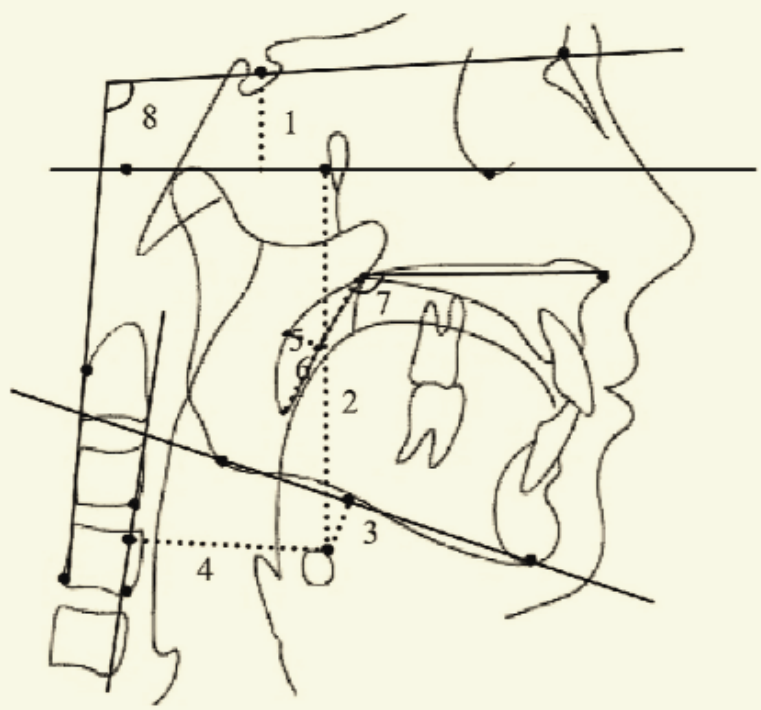

Fig. 4: Hypoid bone, soft palate, and head position measurements. 1) H-S: distance between two perpendiculars from the $\mathrm{H}$ and $\mathrm{S}$ points to the FH plane, representing the front and back positions of the hyoid against the S; 2) H-FH represents the height of the hyoid from the FH plane; 3) H-MP represents the height of the hyoid from the MP plane; 4) H-CVP represents the front and back positions of the hyoid; 5) soft palate thickness (SPT): the widest distance between the perpendicular to the PNS-U connecting line and contour of the soft palate; 6) PNS-U soft palate length; 7) ANS-PNS-U is the front lower angle between the ANS-PNS plane and the connecting line of the PNS-U; and 8) CVT/SN craniocervical angle: angle between the connecting line of the back top protruding point at the second cervical vertebra and the anterior cranial base plane of the back bottom protruding point at the fourth cervical vertebra. 
Table 1: Comparison between the measured items of the mandibular condylar fracture group and those of the normal occlusion group

\begin{tabular}{|c|c|c|c|c|c|}
\hline Measured items & $\begin{array}{c}\text { Normal } \\
\text { occlusion group }\end{array}$ & $\begin{array}{l}\text { Unilateral } \\
\text { mandibular } \\
\text { condylar } \\
\text { fracture }\end{array}$ & $\begin{array}{c}\text { Bilateral } \\
\text { mandibular } \\
\text { condylar } \\
\text { fracture }\end{array}$ & $\begin{array}{c}\text { Normal } \\
\text { occlusion group } \\
v s \text { unilateral } \\
\text { manibular condylar } \\
\text { fracture }(p)\end{array}$ & $\begin{array}{c}\text { Normal } \\
\text { occlusion group } \\
v s \text { bilateral } \\
\text { mandibular condylar } \\
\text { fracture }(p)\end{array}$ \\
\hline \multicolumn{6}{|c|}{ Measurements of the upper airway } \\
\hline PNS-UPW (mm) & $27.48 \pm 3.58$ & $28.09 \pm 4.93$ & $26.50 \pm 5.84$ & 0.873 & 0.700 \\
\hline U-MPW (mm) & $12.86 \pm 2.69$ & $12.23 \pm 3.14$ & $12.29 \pm 3.59$ & 0.719 & 0.757 \\
\hline V-LPW (mm) & $22.99 \pm 4.26$ & $21.46 \pm 3.32$ & $20.79 \pm 3.18$ & 0.272 & 0.082 \\
\hline PAS (mm) & $14.14 \pm 3.03$ & $12.95 \pm 3.35$ & $11.76 \pm 3.55$ & 0.363 & $0.028 *$ \\
\hline \multicolumn{6}{|c|}{ Measurements of the soft palate } \\
\hline ANS-PNS-U $\left(^{\circ}\right)$ & $130.13 \pm 6.59$ & $128.30 \pm 5.48$ & $127.30 \pm 5.46$ & 0.478 & 0.189 \\
\hline PNS-U (mm) & $37.98 \pm 4.27$ & $39.58 \pm 4.47$ & $38.22 \pm 3.88$ & 0.332 & 0.971 \\
\hline SPT (mm) & $7.34 \pm 1.48$ & $8.15 \pm 1.85$ & $7.90 \pm 1.68$ & 0.169 & 0.411 \\
\hline \multicolumn{6}{|c|}{ Measurements of the hyoid } \\
\hline $\mathrm{H}-\mathrm{FH}(\mathrm{mm})$ & $94.44 \pm 6.24$ & $97.08 \pm 8.22$ & $99.28 \pm 8.73$ & 0.394 & 0.058 \\
\hline $\mathrm{H}-\mathrm{S}(\mathrm{mm})$ & $15.84 \pm 6.42$ & $18.11 \pm 7.12$ & $16.97 \pm 7.35$ & 0.431 & 0.802 \\
\hline $\mathrm{H}-\mathrm{CVP}(\mathrm{mm})$ & $42.16 \pm 2.84$ & $42.09 \pm 3.18$ & $40.11 \pm 3.56$ & 0.996 & 0.052 \\
\hline H-MP (mm) & $12.65 \pm 4.56$ & $10.14 \pm 3.48$ & $9.87 \pm 3.16$ & 0.055 & $0.031 *$ \\
\hline \multicolumn{6}{|c|}{ Measurements of the head position } \\
\hline $\mathrm{CVT} / \mathrm{SN}\left({ }^{\circ}\right)$ & $106.87 \pm 6.51$ & $105.45 \pm 6.47$ & $111.40 \pm 7.77$ & 0.696 & $0.042 *$ \\
\hline
\end{tabular}

Table 2: Comparison between the measured items of the mandibular angle fracture group and those of the normal occlusion group

\begin{tabular}{|c|c|c|c|c|c|}
\hline Measured items & $\begin{array}{c}\text { Normal } \\
\text { occlusion group }\end{array}$ & $\begin{array}{c}\text { Unilateral } \\
\text { mandibular } \\
\text { angle } \\
\text { fracture }\end{array}$ & $\begin{array}{c}\text { Bilateral } \\
\text { mandibular } \\
\text { angle } \\
\text { fracture }\end{array}$ & $\begin{array}{c}\text { Normal } \\
\text { occlusion group } \\
v s \text { unilateral } \\
\text { manibular } \\
\text { angle } \\
\text { fracture }(p)\end{array}$ & $\begin{array}{c}\text { Normal } \\
\text { occlusion group } \\
\text { vs bilateral } \\
\text { mandibular } \\
\text { angle } \\
\text { fracture }(p)\end{array}$ \\
\hline \multicolumn{6}{|c|}{ Measurements of the upper airway } \\
\hline PNS-UPW (mm) & $27.48 \pm 3.58$ & $28.35 \pm 4.27$ & $28.51 \pm 4.01$ & 0.657 & 0.556 \\
\hline U-MPW (mm) & $12.86 \pm 2.69$ & $11.66 \pm 3.31$ & $11.43 \pm 3.12$ & 0.280 & 0.173 \\
\hline V-LPW (mm) & $22.99 \pm 4.26$ & $20.51 \pm 3.95$ & $20.03 \pm 3.78$ & 0.058 & $0.020^{*}$ \\
\hline PAS (mm) & $14.14 \pm 3.03$ & $13.02 \pm 3.95$ & $13.27 \pm 3.65$ & 0.432 & 0.595 \\
\hline \multicolumn{6}{|c|}{ Measurements of the soft palate } \\
\hline ANS-PNS-U $\left(^{\circ}\right)$ & $130.13 \pm 6.59$ & $128.09 \pm 5.26$ & $127.09 \pm 4.45$ & 0.342 & 0.108 \\
\hline PNS-U (mm) & $37.98 \pm 4.27$ & $39.62 \pm 4.27$ & $39.92 \pm 4.20$ & 0.299 & 0.193 \\
\hline $\mathrm{SPT}(\mathrm{mm})$ & $7.34 \pm 1.48$ & $8.27 \pm 2.52$ & $8.53 \pm 3.22$ & 0.302 & 0.152 \\
\hline \multicolumn{6}{|c|}{ Measurements of the hyoid } \\
\hline H-FH (mm) & $94.44 \pm 6.24$ & $97.15 \pm 8.81$ & $99.48 \pm 9.90$ & 0.410 & 0.061 \\
\hline H-S (mm) & $15.84 \pm 6.42$ & $18.64 \pm 5.89$ & $19.37 \pm 5.37$ & 0.179 & 0.072 \\
\hline $\mathrm{H}-\mathrm{CVP}(\mathrm{mm})$ & $42.16 \pm 2.84$ & $41.90 \pm 3.09$ & $42.14 \pm 3.13$ & 0.934 & 0.999 \\
\hline H-MP (mm) & $12.65 \pm 4.56$ & $11.86 \pm 3.47$ & $14.73 \pm 4.96$ & 0.750 & 0.174 \\
\hline \multicolumn{6}{|c|}{ Measurements of the head positions } \\
\hline $\mathrm{CVT} / \mathrm{SN}\left({ }^{\circ}\right)$ & $106.87 \pm 6.51$ & $107.50 \pm 8.26$ & $111.91 \pm 6.80$ & 0.933 & $0.027 *$ \\
\hline
\end{tabular}

turcica point $(\mathrm{H}-\mathrm{S})$ significantly decreased $(p<0.05)$, indicating the backward and downward movements of the hyoid. The CVT/SN significantly increased $[p<0.05]$ (Table 3).

\section{Parasymphyseal fracture group}

In the parasymphyseal comminuted fracture group, the space in the PAS and V-LPW was significantly reduced $(p<0.05)$. $\mathrm{H}-\mathrm{FH}$ and H-MP significantly increased $(p<0.05)$, 
Table 3: Comparison between the measured items of the mandibular body fracture group and those of the normal occlusion group

\begin{tabular}{|c|c|c|c|c|c|}
\hline Measured items & $\begin{array}{c}\text { Normal } \\
\text { occlusion group }\end{array}$ & $\begin{array}{c}\text { Unilateral } \\
\text { mandibular } \\
\text { body } \\
\text { fracture }\end{array}$ & $\begin{array}{c}\text { Bilateral } \\
\text { mandibular } \\
\text { body } \\
\text { fracture }\end{array}$ & $\begin{array}{c}\text { Normal } \\
\text { occlusion group } \\
v s \text { unilateral } \\
\text { manibular } \\
\text { body fracture }(p)\end{array}$ & $\begin{array}{c}\text { Normal } \\
\text { occlusion group } \\
v s \text { bilateral } \\
\text { mandibular } \\
\text { body fracture }(p)\end{array}$ \\
\hline \multicolumn{6}{|c|}{ Measurements of the upper airway } \\
\hline PNS-UPW (mm) & $27.48 \pm 3.58$ & $28.44 \pm 4.07$ & $28.22 \pm 4.66$ & 0.658 & 0.777 \\
\hline U-MPW (mm) & $12.86 \pm 2.69$ & $11.34 \pm 3.88$ & $11.34 \pm 3.38$ & 0.326 & 0.181 \\
\hline V-LPW (mm) & $22.99 \pm 4.26$ & $19.79 \pm 3.51$ & $18.78 \pm 4.51$ & $0.023 *$ & $0.002 *$ \\
\hline PAS (mm) & $14.14 \pm 3.03$ & $13.15 \pm 3.95$ & $11.44 \pm 3.58$ & 0.545 & $0.021 *$ \\
\hline \multicolumn{6}{|c|}{ Measurements of the soft palate } \\
\hline ANS-PNS-U $\left({ }^{\circ}\right)$ & $130.13 \pm 6.59$ & $127.00 \pm 4.86$ & $127.67 \pm 5.37$ & 0.141 & 0.284 \\
\hline PNS-U (mm) & $37.98 \pm 4.27$ & $39.73 \pm 4.16$ & $39.84 \pm 4.22$ & 0.294 & 0.255 \\
\hline SPT (mm) & $7.34 \pm 1.48$ & $8.20 \pm 2.58$ & $8.08 \pm 2.09$ & 0.27 & 0.376 \\
\hline \multicolumn{6}{|c|}{ Measurements of the hyoid } \\
\hline H-FH (mm) & $94.44 \pm 6.24$ & $97.93 \pm 7.33$ & $99.94 \pm 5.54$ & 0.132 & $0.010^{*}$ \\
\hline $\mathrm{H}-\mathrm{S}(\mathrm{mm})$ & $15.84 \pm 6.42$ & $14.66 \pm 5.68$ & $11.42 \pm 5.13$ & 0.736 & $0.028^{*}$ \\
\hline $\mathrm{H}-\mathrm{CVP}(\mathrm{mm})$ & $42.16 \pm 2.84$ & $41.27 \pm 3.50$ & $39.36 \pm 3.85$ & 0.584 & $0.012 *$ \\
\hline H-MP (mm) & $12.65 \pm 4.56$ & $10.91 \pm 3.52$ & $13.80 \pm 4.96$ & 0.33 & 0.617 \\
\hline \multicolumn{6}{|c|}{ Measurements of the head position } \\
\hline $\mathrm{CVT} / \mathrm{SN}\left(^{\circ}\right)$ & $106.87 \pm 6.51$ & $107.50 \pm 7.88$ & $112.17 \pm 8.02$ & 0.944 & $0.035^{*}$ \\
\hline
\end{tabular}

indicating the backward and downward movements of the hyoid. H-CVP and H-S significantly decreased $(p<0.05)$, indicating the backward movement of the hyoid. CVT/SN significantly increased $[p<0.05]$ (Table 4 ).

\section{DISCUSSION}

According to the literature, the head position is often represented by the craniocervical angle (8-10). Many studies showed that the upper airway space is readily influenced by

Table 4: Comparison between the measured items of the parasymphyseal fracture group and those of the normal occlusion group

\begin{tabular}{|c|c|c|c|c|c|}
\hline Measured items & $\begin{array}{c}\text { Normal } \\
\text { occlusion group }\end{array}$ & $\begin{array}{l}\text { Parasymphyseal } \\
\text { single-line fracture }\end{array}$ & $\begin{array}{l}\text { Parasymphyseal } \\
\text { comminuted } \\
\text { fracture }\end{array}$ & $\begin{array}{c}\text { Normal } \\
\text { occlusion group } v s \\
\text { parasymphyseal } \\
\text { single-line } \\
\text { fracture }(p)\end{array}$ & $\begin{array}{c}\text { Normal } \\
\text { occlusion group } v s \\
\text { parasymphyseal } \\
\text { comminuted } \\
\text { fracture }(p)\end{array}$ \\
\hline \multicolumn{6}{|c|}{ Measurements of the upper airway } \\
\hline PNS-UPW (mm) & $27.48 \pm 3.58$ & $28.10 \pm 4.22$ & $28.24 \pm 4.56$ & 0.790 & 0.700 \\
\hline U-MPW (mm) & $12.86 \pm 2.69$ & $11.32 \pm 2.97$ & $11.47 \pm 3.47$ & 0.098 & 0.144 \\
\hline V-LPW (mm) & $22.99 \pm 4.26$ & $21.16 \pm 3.49$ & $20.62 \pm 3.40$ & 0.109 & $0.030^{*}$ \\
\hline PAS (mm) & $14.14 \pm 3.03$ & $13.27 \pm 3.82$ & $11.96 \pm 3.21$ & 0.509 & $0.028^{*}$ \\
\hline \multicolumn{6}{|c|}{ Measurements of the soft palate } \\
\hline ANS-PNS-U $\left({ }^{\circ}\right)$ & $130.13 \pm 6.59$ & $128.83 \pm 4.79$ & $127.33 \pm 5.41$ & 0.577 & 0.104 \\
\hline PNS-U(mm) & $37.98 \pm 4.27$ & $40.29 \pm 4.37$ & $39.06 \pm 4.36$ & 0.075 & 0.572 \\
\hline SPT $(\mathrm{mm})$ & $7.34 \pm 1.48$ & $8.15 \pm 1.71$ & $8.05 \pm 1.69$ & 0.106 & 0.171 \\
\hline \multicolumn{6}{|c|}{ Measurements of the hyoid } \\
\hline $\mathrm{H}-\mathrm{FH}(\mathrm{mm})$ & $94.44 \pm 6.24$ & $99.44 \pm 6.53$ & $98.72 \pm 5.11$ & 0.332 & $0.013^{*}$ \\
\hline $\mathrm{H}-\mathrm{S}(\mathrm{mm})$ & $15.84 \pm 6.42$ & $16.17 \pm 5.91$ & $12.15 \pm 4.53$ & 0.964 & $0.026^{*}$ \\
\hline $\mathrm{H}-\mathrm{CVP}(\mathrm{mm})$ & $42.16 \pm 2.84$ & $40.47 \pm 3.02$ & $40.34 \pm 2.90$ & 0.051 & $0.033^{*}$ \\
\hline H-MP (mm) & $12.65 \pm 4.56$ & $15.22 \pm 4.04$ & $15.55 \pm 4.89$ & 0.056 & $0.028 *$ \\
\hline \multicolumn{6}{|c|}{ Measurements of the head position } \\
\hline $\mathrm{CVT} / \mathrm{SN}\left({ }^{\circ}\right)$ & $106.87 \pm 6.51$ & $108.37 \pm 7.95$ & $111.80 \pm 8.00$ & 0.658 & $0.024 *$ \\
\hline
\end{tabular}


the head position. The present study uses the CVT-SN angle to indicate the front lower angle between the anterior cranial base plane and the connecting line between the top protruding point at the back of the second cervical vertebra and the lower protruding point at the back of the fourth cervical vertebra. Changes in the head position may be correlated with and linked to the upper airway space. Thus, controlling the influence of various factors, including the head position, during the study is necessary. The measurements of angles between the $\mathrm{FH}$ plane and the ground greater than $10^{\circ}$ were excluded (11) to reduce the influence of head position and to evaluate the relationship between the cranial maxillofacial morphology and the size of the upper airway. The greater the angle between the FH plane and the ground, and the greater the cranial maxillofacial angle, then the greater the interference on the airway measurement. The craniocervical angle measured in the normal occlusion group was $106.87 \pm 6.51 \mathrm{~mm}$. Those in the bilateral mandibular condylar fracture group, bilateral mandibular angle fracture group, bilateral mandibular body fracture group and parasymphyseal fracture group were $111.40 \pm 7.77 \mathrm{~mm}$, $111.91 \pm 6.80 \mathrm{~mm}, 112.17 \pm 8.02 \mathrm{~mm}$ and $111.80 \pm 8.00$, respectively. Thus, the increasing craniocervical angle is a contributive factor to the abnormal cranial structure. Some studies (12-15) also proved that different types of obstructions in the upper airway can cause the extension of the head position.

The upper airway is a muscular tube surrounded by the tongue, soft palate, posterior and lateral pharyngeal walls, and other soft tissues. The pipe diameter is indirectly influenced by the surrounding hard tissue structure and directly determined by the surrounding soft issue. Therefore, the influence of the soft tissue cannot be disregarded where the maxillofacial bone is concerned. The soft tissue is also a direct factor influencing the size of the upper airway. At the early period after a mandibular fracture (ie three days after mandibular trauma, as chosen in this study), soft tissues were still swollen, accompanied by swelling along the mouth floor, which causes the tongue to push upward and backward, thereby reducing the effective space in the upper airway. The swollen mouth floor causes the epiglottis to shift backward, causing the narrowing of the space in the V-LPW, difficulty in breathing or suffocation in serious cases. Therefore, we also considered soft tissue swelling as an important factor in the changes in the upper airway space, aside from the displacement of the hard tissues because of the fractures. The results show that the backward and downward displacements of the hyoid are the major causes of the narrowing of the lower oropharyngeal airway.

In the unilateral mandibular fracture group, the hyoid position exhibited no significant change; the lower oropharyngeal airway is not closely related to it. In the bilateral mandibular body fracture group and parasymphyseal comminuted fracture group, the distances from the $\mathrm{H}-\mathrm{FH}$ and $\mathrm{H}-$
MP (representing the perpendicular distance of the hyoid) increased; those from the H-CVP and the front and back positions of the H-S (representing the horizontal distance of hyoid) were reduced, indicating that the hyoid moves downward and backward under the action of the muscle groups above and below the hyoid (mainly genioglossus and geniohyoid). The swollen mouth floor lifts the tongue, and the tongue root moves backward, resulting in a narrower airway behind the PAS. After bilateral mandibular condylar fracture, the distance from the $\mathrm{H}-\mathrm{FH}$ increased and that from the H-CVP decreased, with the difference approaching significance. The hyoid bone moves backward and downward, resulting in a narrower airway at the PAS.

In particular, the bilateral mandibular body fracture and parasymphyseal comminuted fracture exhibited the strongest influence, as reflected on the PAS and V-LPW. The bilateral mandibular condylar fracture exhibited a significant influence on the PAS, whereas the two-side mandibular angle fracture significantly influenced the V-LPW. Only the unilateral mandibular body fracture among the unilateral mandibular fractures had apparent significant influence on the VLPW, whereas the other types of fractures did not exhibit significant influence on the upper airway. The influence of fractures on the different parts of the airway is also subject to the traction of the ascending and descending muscle groups in the mandibula (mainly genioglossus and geniohyoid) on the fractured bones. The attached genioglossus moves backward and downward, the mandibula rotates clockwise, and the root of the tongue moves closer to the posterior pharynx wall, resulting in the narrowing of the airway at the PAS, which in turn causes respiratory difficulties. The conclusion is consistent with those of local and international studies (16-19).

The study on the different parts of the airway and the position of the hyoid in mandibular fractures indicates that different fractures have different effects on the upper airway space. In particular, the bilateral mandibular body fracture and the parasymphyseal comminuted fracture have significant influence on the space in the PAS and V-LPW, with serious obstructions severely affecting the ventilatory function of patients. Therefore, relevant therapeutic measures should be adopted in emergency clinics or before surgery for specific types of mandibular fractures to prevent breathing obstructions and alleviate breathing problems. This study provides theoretical support for the efficient assessment of risk factors in trauma patients, necessity for surgery, degree of difficulty of anaesthetic intubation, and postoperative prognosis.

Conflict of interest: The authors declare that they have no conflict of interest.

\section{REFERENCES}

1. Zhang ZK, Yu GG. Oral and maxillofacial trauma. Oral Maxillofac Surg 2007; 5: 255-7. 
2. Liu YH, Zeng XL, Fu MK, Huang XZ. X-ray cephalometry study of normal people's upper airway structure orthodontics. Chin J Orthodontics 1997; 4: 10-4.

3. Fu MK, Tian NX. Theory and practice of oral X-ray cephalometry. Beijing: People Health Publishing House; 1991; 13-9.

4. Lowe AA, Santamaria JD, Fletham LA, Price C. Facial morphology and obstructive sleep apnea. Am J Orthod Dentofaci-Orthop 1986; 90: 484-91.

5. Hiyama S, Suda N, Ishii-Suzuki M, Tsuiki S, Ogawa M, Suzuki S et al. Effect of maxillary protraction on craniofacial structures and upperairway dimension. Angle Orthod 2002; 72: 43-7.

6. Han DM. Surgery for sleep disordered breathing. $1^{\text {st }}$ ed. Beijing: People Health Publishing House; 2006; 73-7.

7. Ferguson KA. The role of oral appliance therapy in the treatment of obstructive sleep apnea. Clin Chest Med 2003; 24: 355-64.

8. Solow B, Sandham A. Cranio-cervical posture: a factor in the development and function of the dentofacial structures. Eur J Orthod 2002; 24: $447-56$.

9. Oktay H, Ulukaya E. Maxillary protraction appliance effect on the size of the upper airway passage. Angle Orthod 2008; 78: 209-14.

10. Muto T, Takeda S, Kanazawa M, Yamazaki A, Fujiwara Y, Mizoguchi I. The effect of head posture on the pharyngeal airway space (PAS). Int J Oral Maxillo Surg 2002; 31: 579-83.

11. Trenouth MJ, Timms DJ. The relationship of the functional oropharynx to craniofacial morphology. Angle Orthod 1999; 69: 419-23.
12. Woodside $\mathrm{D}$, Linder-Aronson $\mathrm{S}$. The channelization of upper and lower anterior face heights compared to population standards in males 6 to 20 years. Eur J Orthod 1979; 1: 25-40.

13. Vig PS, Showfety KJ, Phillips C. Experimental manipulation of head posture. Am J Orthod 1980; 77: 258-68.

14. Wenzel A, Hensgaard E, Henriksen JM. Craniofacial morphology and head posture in children with asthma and perennial rhinitis. Eur J Orthod 1985; 7: 83-92.

15. Goncalves JR, Buschang PH, Goncalves DG, Wolford LM. Postsurgical stability of oropharyngeal airway changes following counterclockwise maxillo-mandibular advancement surgery. J Oral Maxillofac Surg 2006; 64: 755-62.

16. Zhang L, Gu XM. Study on positions of hyoid and changes of lower pharynx airway before and after orthognathic surgery. Oral Maxillo Surg Magazine 1999; 9: 306-9.

17. Mehra P, Downie M, Pita MC, Wolford LM. Pharyngeal airway space changes after counterclockwise rotation of the maxillomandibular. Am J Orthod Dentofacial Orthop 2001; 120: 154-61.

18. Chen FS, Terada K, Hanada K, Saito I. Predicting the pharyngeal airway space after mandibular setback surgery. J Oral Maxillofac Surg 2005; 63: 1509-14.

19. Tselnik M, Pogrel MA. Assessment of the pharyngeal airway space after mandibular setback surgery. J Oral Maxillofac Surg 2000; 58: $282-5$. 